\title{
Analisis Nilai-Nilai Agama dan Moral Anak Usia Dini dalam Tayangan Film Kartun Upin dan Ipin
}

\author{
Syisva Nurwita ${ }^{\bowtie}$ \\ Pendidikan Guru Pendidikan Anak Usia Dini, Universitas Dehasen Bengkulu
}

\begin{abstract}
Abstrak
Tujuan penelitian ini adalah menganalisis dan mendeskripsikan nilai moral dalam film kartun upin dan ipin. Jenis penelitian ini adalah Deskriptif Kualitatif menggunakan sampel judul "Ramadhan" dengan teknik Content Analisis. Data berupa hal-hal yang mengandung nilai agama dan moral yang terdapat pada film kartun upin dan ipin. Hasil penelitian didapatkan bahwa nilai agama dan moral terdapat pada masing-masing judul film kartun upin dan ipin. Nilai agama dan moral tersebut adalah rasa hormat, tanggung jawab, kejujuran, keadilan, toleransi, kebijaksanaan, disiplin diri, tolong menolong, peduli sesame, kerja sama, keberanian, dan demokratis. Film kartun Upin Ipin direkomendasikan untuk terus ditonton oleh anak-anak karena didalamnya terkandung nilai agama dan moral sesuai dengan budaya bangsa dan agama Islam
\end{abstract}

Kata Kunci: cartoon upin ipin, religious and moral values, early childhood

\begin{abstract}
The purpose of this study was to analyze and describe the moral values in upin and ipin cartoons. This type of research is descriptive qualitative using a sample title "Ramadan" with Content Analysis techniques. Data in the form of things that contain religious and moral values contained in upin and ipin cartoons. The results showed that religious and moral values were found in each of the upin and ipin cartoon titles. These religious and moral values are respect, responsibility, honesty, fairness, tolerance, wisdom, self-discipline, help, care for others, cooperation, courage, and democracy. The cartoon film Upin Ipin is recommended to be watched by children because it contains religious and moral values in accordance with the culture of the nation and the religion of Islam.
\end{abstract}

Keyword : film kartun upin ipin, nilai agama dan moral, anak usia dini

Copyright (c) 2019 Syisva Nurwita

$\triangle$ Corresponding author :

Address : De'Sanctuary D/28 Bekasi

Email : rd.ardiyana@gmail.com

ISSN $\underline{2356-1327}$ (Media Cetak)

ISSN 2549-8959 (Media Online) 


\section{PENDAHULUAN}

Pendidikan nilai-nilai agama dan moral merupakan pondasi yang kokoh dan sangat penting keberadaannya, dan jika hal itu telah tertanam dalam diri anak sejak dini, hal ini merupakan awal yang baik bagi pendidikan anak bangsa untuk menjalani jenjang pendidikan selanjutnya. Untuk mengembangkan aspek tersebut tentunya dibutuhkan strategi maupun model pembelajaran yang tepat di sekolah atau dirumah.

Penanaman nilai dalam bentuk praktek etika, ritual, atau budi pekerti tidak akan cukup hanya diberikan sebagai pelajaran yang konsekwensinya hafalan atau secara tertulis, namun dapat ditarik kearah kognitif, efektif, dan fisik motorik dengan menyaksikan langsung sebuah peristiwa-peristiwa yang nyata dan di rangkum dalam bentuk lain. Sehingga, orang tua maupun pendidik kadang merasa kesulitan dalam menanamkan nilai-nilai pendidikan agama dan moral pada anak usia dini terutama dalam ibadah, berdoa dan menghargai sesama manusia, ini yang menyebabkan banyak para orang tua maupun pendidik merasa gagal dalam mendidik anak (peserta didik). Namun sebagaimana telah kita ketahui bahwa kini media film merupan hal yang cukup ampuh karna film dapat dilihat secara langsung gerak-gerik, serta tingkah laku pemainnya, sehingga kemungkinan untuk ditiru akan lebih mudah.

Pada 5 tahun terakhir dunia perfilman semakin menjamur, bagi TV swasta maupun local, melalui internetpun kita dapat mengakses film, rental-rental video CD film banyak tersedia, dan menonton film di bioskopun menjadi tempat favorit masyarakat sampai saat ini. Hal yang lebih menarik adalah perdebatan dikalangan dewasa tentang film bagi anak-anak, karna melihat menu tayangan TV yang banyak pula memberi efek negatif pada anak-anak. Dari segi tema, para produsen beranggapan bahwa masyarakat umum dan anak-anak pada khususnya memerlukan tokoh dalam kehidupannya, karena film itu sendiri berfungsi sebagai media penerangan dan pendidikan secara penuh. Artinya film bukan sekedar alat bantu, juga tidak perlu dibantu dengan penjelasan, melainkan sebagai media penerangan dan pendidikan terlengkap.

Orang tua harus mempunyai tontonan film yang sehat untuk membawa anakanaknya pada perkembangan fisik dan kejiwaan yang positif. Disamping itu tontonan dapat mempengaruhi karaker anak. Karakter adalah tindakan yang dilakukan tanpa pemikiran dan pertimbangan terlebih dahulu. Jadi orang yang berkarakter adalah orang yang melakukan dan merespon sesuatu dengan spontan dan reflek. (Hamid \& Istianti, 2017)

Sedangkan tujuan pengembangan nilai agama dan moral menurut Rizki Ananda adalah adalahmempersiapkan anak sedini mungkin mengembangkan sikap dan perilaku yang didasari oleh nilai agama dan moral sehingga dapat hidup sesuai dengan norma-norma yang dianut oleh masyarakat.(Ananda, 2017)

Karakter dikembangkan melalui tahap pengetahuan

(knowing),pelaksanaan(acting), dan kebiasaan (habit). Karakter tidak terbatas pada pengetahuan saja. Seseorang yang memiliki pengetahuan kebaikan belum tentu mampu bertindak sesuai dengan pengetahuannya, jika tidak terlatih (menjadi kebiasaan) untuk melakukan kebaikan tersebut.(Rohmah, 2018)

Seperti halnya film kartun kisah-kisah para nabi dan sahabatnya, sayangi makhluk allah, dan Upin Ipin yang banyak mengandung nilai agama dan moral sebagaimana kita ketahui bahwa diantara 
film animasi anak yang paling popeler dikalangan masyarakat saat ini adalah film Upin dan Ipin. Para orang tuapun memberikan tontonan ini kepada anakanaknya karna rasa percaya mereka terhadap pendidikan agama dan moral yang terkandung di dalamnya. Selain itu, para tokoh yang berperanpun seakan memasuki dunia nyata bagi anak sehingga imajinasi anak dapat berkembang secara positif.

Film kartun Upin dan Ipin pada episode 1 (Esok Puasa) - episode 2 (Berkat) yang dapat menginspirasi bagaimana hidup dalam kesederhanaan. Film ini bercerita tentang kehidupan sehari-hari dua orang anak kecil dan teman-temannya pada saat bulan ramadhan hingga menuju hari kemenangan umat islam. Film ini sarat akan nilai keagamaan bagi umat islam maupun kehidupan sosial beragama. Tidak seperti film animasi anak lainnya yang hanya menampilkan kegembiraan maupun hurahura.

Nilai pendidikan sebuah film jangan diartikan sebagaimana di bangku sekolah. Nilai sebuah film dimaksudkan bermakna semacam pesan-pesan, atau katakanlah moral film, yang semakin harus menggarapnya akan semakin baik pula tujuan yang hendak di capai. Dengan demikian, penonton tidak merasa dirugikan. Hampir semua film mengajari atau memberitahu kita tentang sesuatu. Namun, bila animasi lain masih menyisakan adegan kekerasan, perkelahian, dan caci maki, dalam film Upin Ipin semua itu tidak ada. Tayangan ini disajikan sederhana, namun komunikatif dan mendidik. Sajiannya juga mencerdaskan, dan mencerahkan

Perkembangan moral menurut Kohlberg meliputi: Pra-konfensional: penekanan pada control eksternal, orientasi pada hukum dan kepatuhan. Orientasi instrumental relative, konvensional, orientasi hubungan manusia, orientasi pada pemeliharaan system sosial, akhir konvensional internal, orientasi kontrak sosial, dan orientasi prinsip etis

Selanjutnya, perkembangan keagamaan anak menurut Elkind dalam Suyadi (2010). Pertama, Pencarian untuk konservasi. Penyebutan ini berdasarkan ide bahwa anak-anak memiliki ketetapan sebagai objek yang mempunyai kekurangan. Pada tahap ini, anak-anak menganggap hidup adalah abadi.

Moralitas anak pada usia dini dan perkembangannya dalam tataran kehidupan dunia mereka (Otib, 2005) terdiri dari sikap dan cara berhubungan dengan orang lain (Sosialisasi) dan cara berpakaian dan berpenampilan dan Sikap dan kebiasaan makan serta sikap dan perilaku anak yang memperlancar hubungannya dengan orang lain.

Pada anak taman kanak-kanak, halhal seperti itu harus dimulai dan diajarkan. Anak harus tau dimana dan pada situasi apa dia boleh menggunakan baju tidur atau bila kesekolah memakai seragam sekolah, harus memakai seragam sekolah selain itu cara bersolek, bersikap dan berpenampilan yang bagaimana, yang dianggap pantas dengan situasi dan orang yang dihadapinya. Tentu saja dengan usianya yang relative masih sangat muda, hal-hal tersebut tidak semuanya harus sengaja diajarkan kepada anak-anak. Kesempatan untuk mengajarkan hal-hal seperti itu seringkali tergantung dari kejadian atau pengalaman yang terjadi kepada anak.

Kegiatan makan memang bukan merupakan kegiatan yang langsung berhubungan dengan orang lain, tetapi hal itu biasanya dilakukan atau diantara orang lain. Ada tata cara tertentu yang di atur oleh lingkungan sekitar dalam melakukan kegiatan makan ini. Penyesuaian diri sangat berpengaruh diri individu dalam lingkungan sosial sekitarnya. Tata cara tersebut harus sudah dikenalkan dan diajarkan kepada anak usia dini, agar menjadi kebiasaan yang 
baik dan mengarahkan pada perilaku moral yang baik.

Banyak orang yang tidak menyadari bahwa sikap dan perilakunya merugikan atau menyakiti orang lain, sehingga menghambat kelancaran hubungannya dengan orang lain. Hal ini pada dasarnya dipengaruhi oleh sikap egois (hanya mementingkan diri sendiri) dan acuh tak acuh terhadap kepentingan orang lain. Ketika anak memasuki usia pra-sekolah, seiring dengan perkembangan berbahasa dan berpikirnya berbagai informasi yang dilihat dan didengarnya dapat merupakan pelajaran yang baik.

Pada anak seusianya walaupun perilakunya tersebut belum dikatakan bermoral, tetapi dinilai sudah melampaui batas kewajaran dan perlu mendapat perhatian yang serius dari pendidik (orang tua dan guru) agar tidak berlanjut hingga besar dan berkembang menjadi perilaku yang tidak baik.

Menurut Ditjen Dikdasmen RI (Otib, 2005) Anak usia dini dalam pandangan ilmu psikologi memiliki keunikan, karakter khusus, dan kemampuan meniru yang luar biasa, serta rasa ingin tahu yang tinggi. Hal itu tentunya sangat perlu kita jadikan landasan utama pada saat kita akan mengembangkan berbagai potensi anak termasuk di dalamnya masalah pengembangan nilai-nilai agama.

Dengan demikian seyogyanya kita menentukan atau memberikan ruang lingkup pengembangan nilai-nilai agama kepada anak dimulai dari kebutuhan anak tentang rutinitas kehidupan pribadi anak mulai dari mereka bangun tidur sampai tidur kembali. Kegiatan itulah yang harus kita warnai dengan nuansa dan nilai-nilai ritualitas secara mendalam. Hal tersebut dilakukan dalam rangka menanamkan benih-benih keimanan dan ketaqwaan sedini mungkin dalam kepribadian anak didik sebagaimana terlihat dalam perkembangan kehidupan jasmani dan rohani sesuai dengan tingkat perkembangannya.

Ada tiga aspek yang harus diperhatikan dalam menetapkan tujuan penanaman nilai-nilai keagamaan kepada anak usia dini, yaitu aspek usia, aspek fisik, dan aspek psikis. Nilai keagamaan anak dipengaruhi oleh faktor pembawaan, faktor lingkungan (Otib, 2005).

Anak banyak belajar dari apa yang mereka lihat dan saksikan secara langsung. Mereka banyak meniru dari apa yang mereka lihat sebagai sebuah pengalaman belajar. Untuk itu perlu guru dan orang tua mempersiapkan diri dalam hal pemberian contoh. Kuasailah materi yang akan diajarkan kepada anak-anak agar kita dapat mengajarkannya dengan benar. Karena apabila kita memberikan contoh yang salah maka anak pun akan meniru dengan contoh yang salah pula. Sifat pembelajaran agama pada anak usia dini berupa; mudah diterapkan, menyenangkan, dan mudah ditiru. Audio visual berupa film merupakan salah satu contoh pembelajaran yang mencakup hal tersebut.

Film mempunya keunggulan sebagaimana dikemukakan oleh Sukenti yaitu: merupakan suatu dominator belajar yang umum, sangat bagus untuk menerangkan suatu proses, dapat menyajikan baik teori maupun praktek, dapat mengikat perhatian anak, lebih realitis, dapat diulang-ulang, dihentikan dan sebagainya, sesuai dengan kebutuhan, mengatasi keterbatasan daya indera kita (penglihatan) film dapat merangsang atau memotivasi kegiatan anak-anak.(Sukenti, 2011)

Selain keunggulan dikemukakan di atas, film juga mempunyai beberapa kekurangan sebagai berikut; bersuara tidak dapat diselingi dengan keteranganketerangan yang diucapkan sewaktu film diputar, penghentian pemutaran akan 
mengganggu konsentrasi audien, audien tidak akan dapat mengikuti dengan baik kalau film diputar terlalu cepat, apa yang telah lewat sulit untuk diulang kecuali memutar kembali secara keseluruhan, dan biaya pembuatan dan peralatannya mahal (Sukenti, 2011)

Menurut Sadiman dkk. Menyebutkan film merupakanmedia yang amat besar kemampuannya dalam membantu proses belajar mengajar (Sadiman \& Dkk., 1990)

Daryanto menyebutkan bahwa kartun adalah gambaran tentang seseorang, suatu buah pikiran atau keadaan dapat diluangkan dalam bentuk lukisan yang lucu. (Daryanto, 2010)

Tayangan film kartun Upin dan Ipin adalah sesuatu bentuk program penyajian yang diproduksi oleh ahli pembuat film yang tokohnya sepasang anak kembar bernama Upin dan Ipin yang hidup dari keluarga sederhana dan selalu hidup dalam kesederhanaan, kemudian dipertunjukan dan ditayangkan melalui gambar interpretative yang menggunakan simbolsimbol untuk menyampaikan sesuatu pesan secara cepat dan ringkas atau sesuatu sikap terhadap orang, situasi atau kejadiankejadian tertentu, sehingga ini dapat menimbulkan daya tarik tersendiri ketika anak menontonnya, sebab film kartun Upin dan Ipin ini menggambarkan proses kehidupan dan mencakup pengalaman tentang dunia anak.

\section{METODOLOGI}

Penelitian ini menggunakan pendekatan Deskriptif sebagai prosedur penelitian yang menghasilkan data deskriptif yang berupa pemaparan secara keseluruhan. Metode yang digunakan dalam penelitian ini adalah Content Analisis atau Analisis isi. Sumber data utama dalam penelitian ini adalah isi Film Kartun Upin dan Ipin dari media televisi. Karya ini memiliki latar belakang religius yang tertanam di dalamnya. Menggunakan data premier isi film kartun Upin Ipin episode 1 Esok Puasa, Seri ke 2 dalam episode 9 (Adat), Episode14 (Ketupat), dan Episode 17 (Pagi raya) dengan data sekunder berbagai tulisan yang membahas mengenai isi film Upin Ipin dari penelitian terdahulu dan internet. Instrument penelitian yang digunakan ialah Catatan Anekdot, Observasi Dokumen, Film Kartun Upin dan Ipin.

\section{HASIL DAN PEMBAHASAN}

Terdapat 9 nilai agama dan moral yang dapat ditemukan dalam film kartun Upin dan Ipin pada episode yang dianalisis yaitu ; kepatuhan, toleransi, menahan nafsu, memberi dan menjawab salam, jujur, saling berbagi, tolong menolong, saling memaafkan dan berterima kasih.

\section{Kepatuhan}

Seri pertama episode satu berjudul "Esok Puasa" terdapat nilai agama dan moral yaitu Patuh, sebagaimana terdapat pada dialog di bawah ini :

Ketika upin, ipin, mei-mei dan raju sedang bermain kelereng, saat itu terdengar azan magrib.

Upin: "Hah! Magrib, Cepat balik !"

Raju: “Hey, nak kemane?”

Kak Ros: "Ha, cepat masuk !mandi, lepas sembahyang mengaji !"

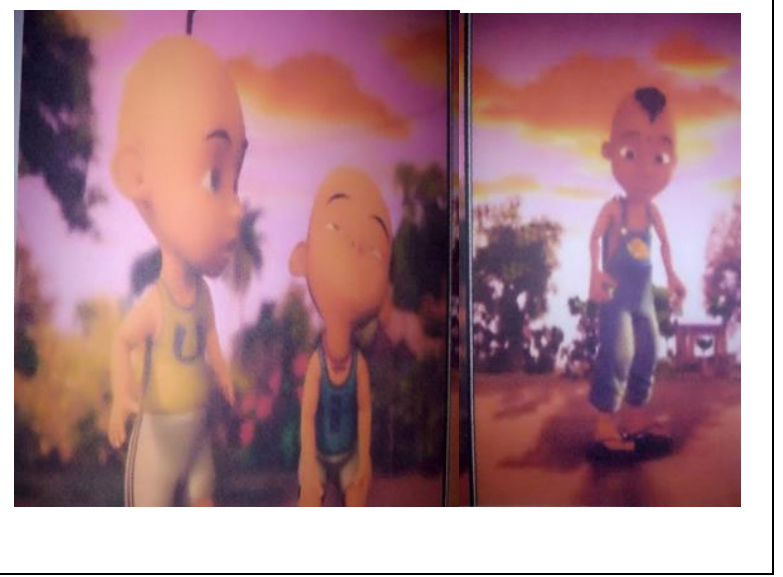


511 | Analisis Nilai-Nilai Agama dan Moral Anak Usia Dini dalam Tayangan Film Kartun

\section{Toleransi}

Seri Pertama Episode Satu yang berjudul "Esok Puasa" terdapat nilai agama dan moral yaitu Toleransi, sebagaimana terdapat pada dialog di bawah ini :

Upin: "Kenape kita ke nak pause Opah ?" Mak Uda: "Orang islam wajib pause, Tuhan suruh. Supaya kite tau macammane rasanye orang kelaparan"

Upin: "Tapi Opah, kite orang kecik lagi.."

Mak Uda: "Yelah, kecik-kecik lah kenak belajar puase"

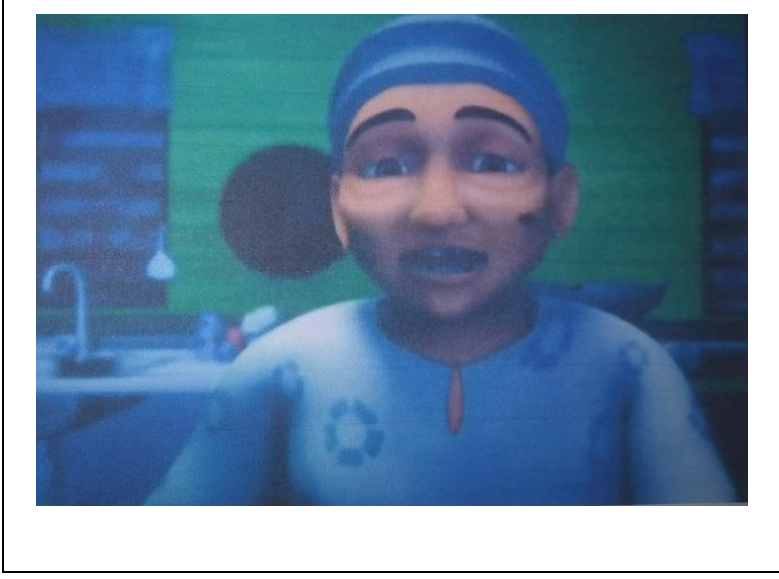

\section{Menahan Nafsu}

Dalam Film Kartun Upin dan Ipin Seri Kedua Episode Sembilan yag berjudul "Adat" terdapat nilai agama dan moral yaitu :Menahan nafsu, sebagaimana terdapat dialog di bawah ini:

Ipin : "Wuuu...Sedapnye bau,,,.. Eh, saba ipin, saba! Puase"

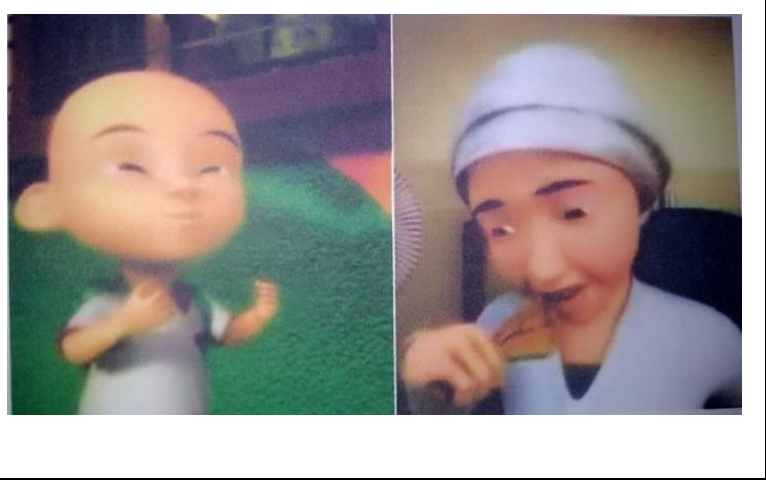

\section{Memberi dan membalas salam}

Dalam Film Kartun Upin dan Ipin seri kedua episode Sembilan yang berjudul "Adat" terdapat nilai Agama dan Moral yaitu : Memberi dan membalas salam, sebagaimana terdapat pada dialog dibawah ini :

Upin dan Ipin : “Assalamu'alaikum..."

Upin : "Atok..."

Ipin : "Ooo Atok"

Tok Dalang: "Wa'alaikumsalam...ha, orang nak ape nih?"

Upin: "Nih tok, Opah bagi makanan untuk buka puase"

Tok Dalang: "Hmmm, sedap... Terima kasih ya."

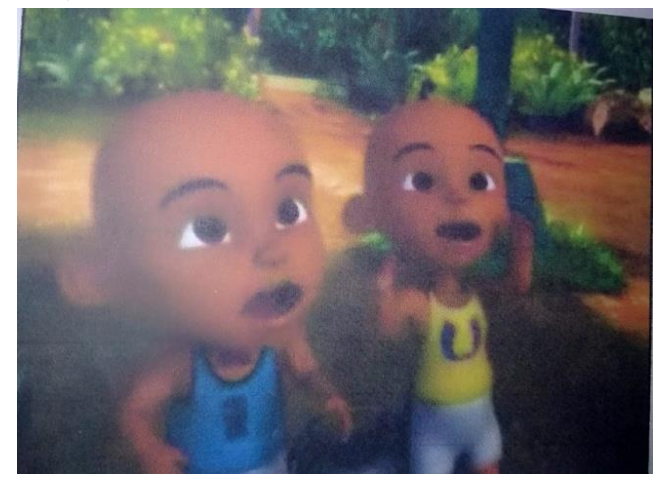

\section{Jujur}

Dalam Film Kartun Upin dan Ipin Seri Kedua Episode Sembilan yag berjudul "Adat" terdapat nilai Agama dan Moral yaitu : Bersyukur, sebagaimana terdapat pada dialog dibawah ini :

Upin: "Opah, Opah dekat sekolah tadi, ramai kawan-kawan yang tak pause Opah. Die orang bawa bekal. Tergugah iman Ipin" Ipin: "Ih..tak de, tak de"

Kak Ros: "Habis kau minum tak ?"

Upin: "Eh, tak Upin tengok aja, iman Upin kuat" 


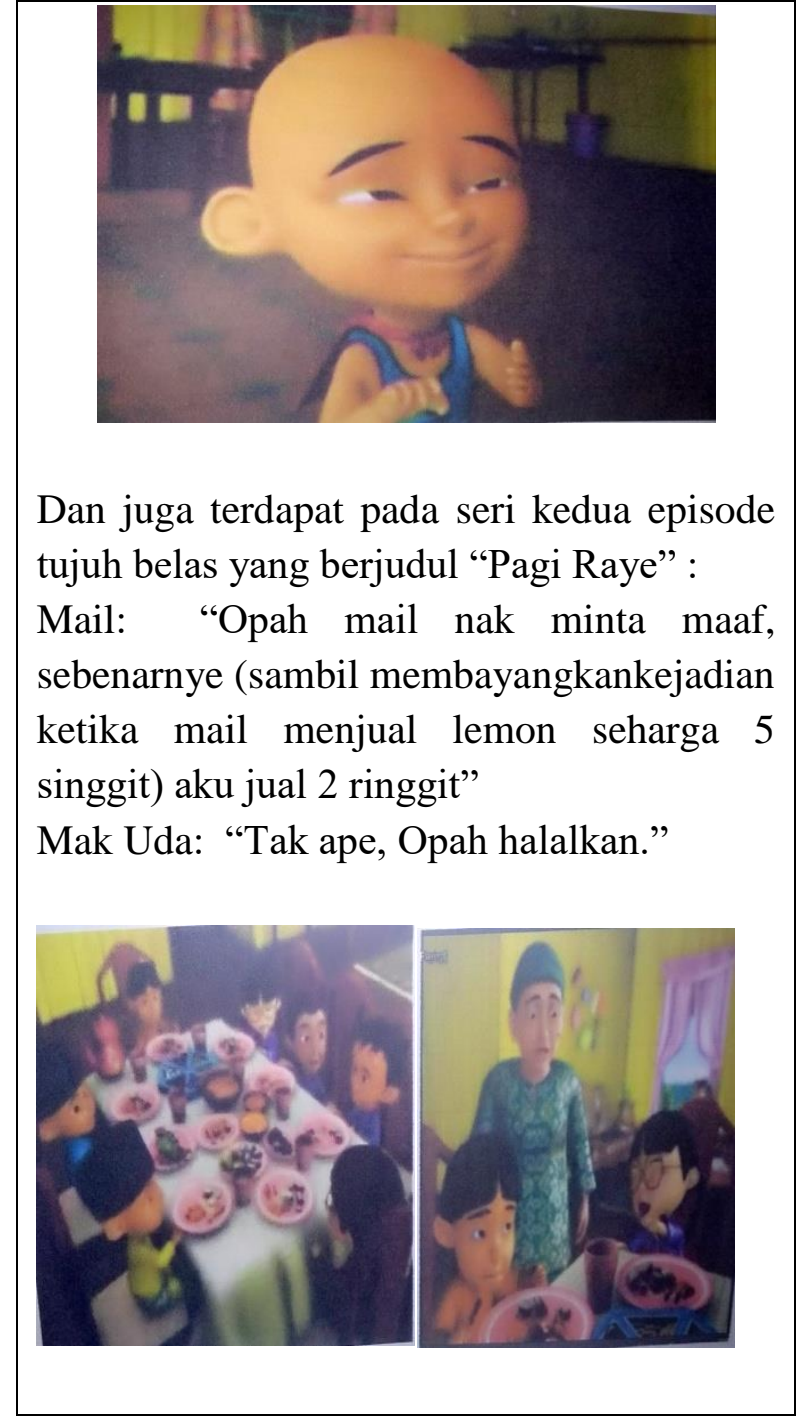

\section{Saling Berbagi}

Seri kedua episode Sembilan yang berjudul "Adat" terdapat nilai agama dan moral yaitu Sedekah, sebagaimana terdapat pada dialog di bawah ini :

Mak Uda: "Nah anta ni (rantang) ke rumah tok Dalang"

Upin: "Ha a, buat apa?"

Ipin: "Ha a, cukup ke makanan ? Opah masak banyak keh ?"

Mak Uda: "Cukup, bulan puase ni elok la bersedekah, inikan adat kite"

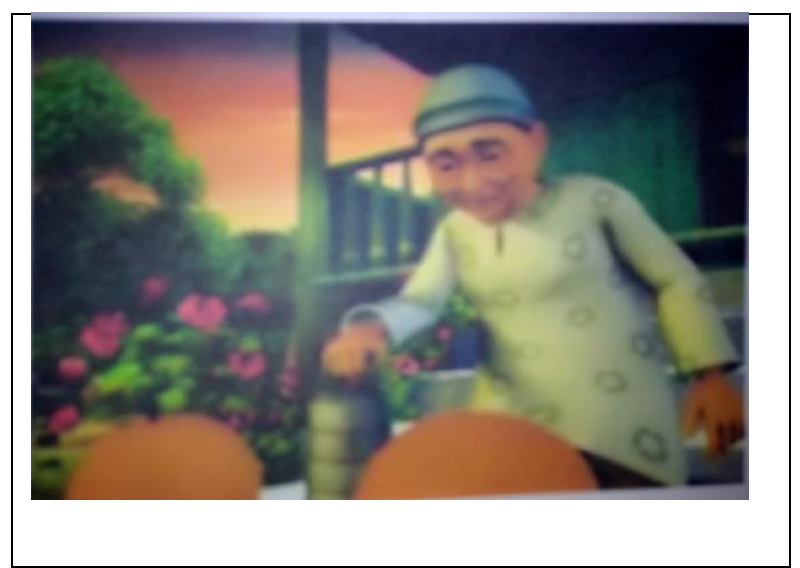

\section{Tolong Menolong}

Dalam Film Kartun Upin dan Ipin seri kedua episode empat belas yang berjudul "Ketupat" terdapat nilai Agama dan Moral yaitu Tolong Menolong, sebagaimana terdapat pada dialog di bawah ini :

Kak Ros dan Opah sedang membuat ketupat, setelah itu upin dan ipin datang.

Upin: "Akak, nak kite orang tolong ?"

Kak Ros: "Tak nak"

Ipin: "Naklah kak"

Kak Ros: "Orang kate tak nak, tak nak lah..."

Mak Uda: "Alah ros, bialah die orang tolong, duduk...duduk...!"

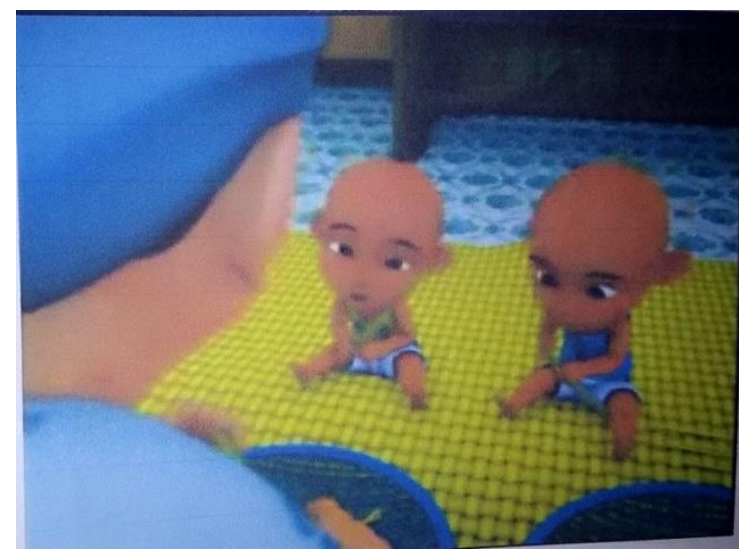




\section{Saling Memaafkan}

Seri kedua episode tujuh belas yang berjudul "Pagi Raye" terdapat nilai agama dan moral yaitu saling memafkan, sebagaimaa terdapat pada dialog di bawah ini :

Upin: "Opah, nak salam. Minta Maaf ye Opah, kite orang memangnakal, tapi Opah tak pernah marah, betul kan Ipin ?"

Ipin: "Betul, betul,betul, kita sayang Opah, kita doakan opah panjang umur"

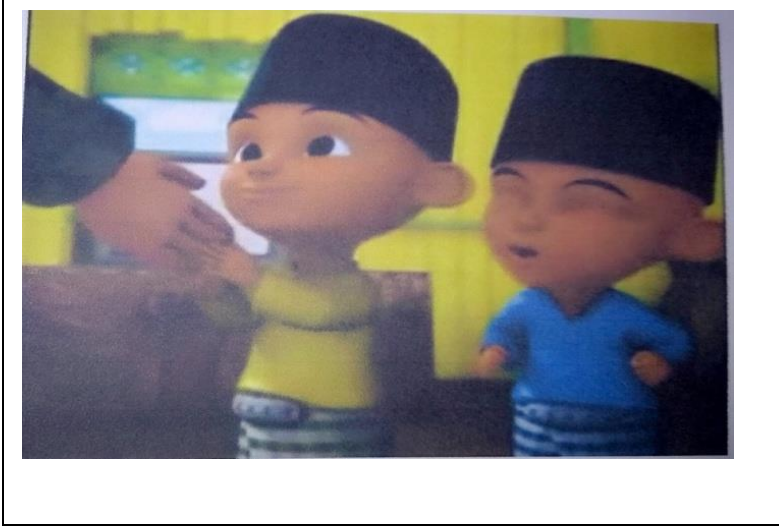

\section{Terima kasih}

Seri kedua episode tujuh belas yang berjudul "Pagi Raya" terdapat nilai agama dan moral yaitu berterima kasih saat memperoleh sesuatu, sebagaimana terdapat pada dialog dibawah ini :

Kak Ros: "Wah, cantiknye baju"

Upin: "Tengoklah, siape yang pakai ! Kita orangkan comel"'

Ipin: "Betul-Betul"

Kak Ros: "Hmmm"

Upin: "Yela,yela, akak emang pandai jahit baju. Kite sayang akak."

Ipin: "Betul, terima kasih akak."

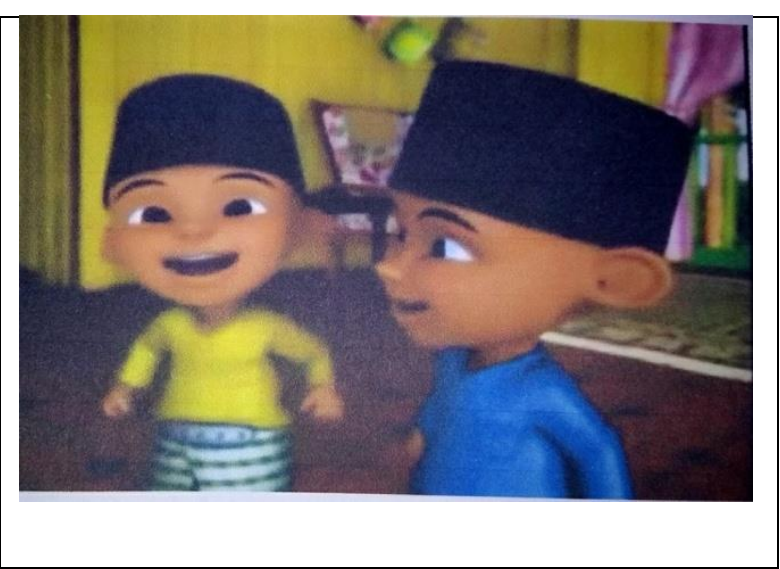

\section{Pembahasan}

Kepatuhan

Dialog yang menunjukkan sikap kepatuhan: Upin ;’Hah! Maghrib, cepat balik!'” Raju ;'Hey, nak kemane?"

Kak Ros;'Ha, cepat masuk! Mandi, lepas sembahyang mengaji!"

Makna dialog diatas ketika Upin dan Ipin sedang bermain kemudian maghrib pun tiba, hal ini ditandai suara azan yang berkumandang dari surau dikampung mereka, ketika itu pula Upin tersadar bahwa seharusnya mereka berhenti bermain hingga bergegas mengajak Ipin adiknya untuk segera pulang, kak Ros juga tidak lupa mengingatkan adik kembarnya untuk segera membersihkan diri untuk ibadah Maghrib. Hal ini tampak bahwa Upin dan Ipin menunjukkan kepatuhan dan mempunyai rasa taat kepada tuhan, orang tua dan tidak ragu-ragu dalam mengerjakan suatu kebaikan.

Hal ini berhubungan dengan pernyataan PUSKUR (Pusat Kurikulum) 2002 dalam Setiawati (2006) Secara umum pendidikan pada anak usia dini bertujuan untuk membantu mengembangkan seluruh potensi dan kemampuan fisik, intelektual, emosional, agama dan moral secara optimal pada anak dalam lingkungan pendidikan yang kondusif, demokratis, dan kompotitif. Sementara itu nilai Kepatuhan terdapat dalam penjabaran Indikator perilaku agama dan moral sejak usia 1 hingga 6 Tahun, 
514 | Analisis Nilai-Nilai Agama dan Moral Anak Usia Dini dalam Tayangan Film Kartun

yaitu NAM.12: Berlatih untuk selalu tertib dan patuh pada aturan, mengurus diri sendiri.

\section{Toleransi}

Dialogyang menunjukkan sikap toleransi Upin: "Kenape kita ke nak puasa Opah?" Mak Uda: "Orang islam wajib puase, Tuhan suruh. Supaye kite tau macam mane rasenye orang kelaparan"

Upin: "Tapi Opah, kite orang kecik lagi..."

Mak Uda: "Yelah, kecik-kecik lah kenakbelajar puase"

Makna dialog diatas menunjukkan bahwa Opah menerangkan kepada kedua cucunya yang masih belia itu tentang wajib puasa. Sebab puasa merupakan kewajiban dan perintah tuhan. Dan Opah juga menerangkan bahwa makna puasa terdapat rasa toleransi kita kepada orang-orang yang kelaparan, sehingga ketika kita selalu mendapatkan nikmat dariNya maka kita akan selalu bersyukur kepada Tuhan yang Maha Esa.

\section{Menahan Nafsu}

Dialog yang menunjukkan Menahan nafsu: Ipin:"Wuuu...sedapnye bau, eh, saba Ipin, saba! Puase!"

Dari dialog diatas dapat digambarkan bahwa pada saat itu Ipin dan temantemannya sudah pulang sekolah, namun belum sempat keluar pagar dari sekolah Ipin ingat bahwa laba-laba miliknya ketinggalan dalam laci mejanya dikelas. Tiba-tiba Ipin mencium Aroma makanan dari suatu ruangan, walaupun baunya sedap namun Ipin berhasil mengendalikan dan menahan nafsunya.

\section{Memberi Salam dan Membalas Salam}

Dialog yag menunjukkan member dan menerima salam :

Upin dan Ipin: "Assalamu'alaikum..."

Upin: "Atuk..."
Ipin: "Ooo Atuk"

Tuk Dalang: "Wa'alaikumsalam... ha, orang nak apa nih ?"

Upin: "Nih tuk, Opah bagi makanan untuk buka puase"

Tuk Dalang: "Hmmm, Sedap... Terimakasih ya."

Makna dialog diatas ketika upin dan ipin tiba mengantarkan makana di rumah tuk dalang mereka terlebih dahulu mengucapkan salam dengan serentak di depan pintu masuk rumah tuk dalang, dan mendengar salam itu tuk Dalang pun lansung membuka pintu rumahnya seraya menjawab salam dari kedua beradik kembar itu. Hal ini berhubungan dengan perkembangan dasar pada indicator Permendiknas Nomor 58 tentang anak usia 4-5 tahun yaitu terbiasa berprilaku sopan santun dan saling menghormati sesama, hingga dapat dikembagkan menjadi memberi dan menerima salam (NAM 10).

\section{Jujur}

Dialog yang menunjukkan sifat jujur :

Upin: "Opah, Opah, dekat sekolah tadi, ramai kawan-kawan yang tak puase Opah. Die orang bawa bekal, Tergugah iman Ipin" Ipin: "Ih. . tak de, tak de"

Kak Ros: "Habis kau minum tak ?"

Upin: "Eh, tak Upin tengok je, Iman Upin kuat."

Dialog sikap jujur lainnya :

Mail: "Opah Mail nak minta maaf, sebenarnya (sambil membayangkan kejadian ketika mail menjual lemang seharga 5 ringgit) aku jual2 ringgit"

Mak uda: "Tak Ape, Opah halalkan."

Makna dialog di atas Upin dan ipin mengakui beratnya menahan haus dan lapar ketika puasa, meskipun demikian, mereka tetap berusaha menjaga puasanya hingga tiba waktu berbuka. Hal ini tampak bahwa mereka jujur dan tidak memanfaatkan situasi menggugahkan saat saat bersama teman-temannya yang masih membawa 
bekal di bulan Ramadhan. Pada dialog kedua Mail pun mau mengakui kesalahannya dan kepada Opah bahwa ketika ia menjual lemang kepada Opah seharga 5 ringgit, dan harga lemang sebenarnya adalah 2 ringgit. Opah pun senantiasa memberikan mereka maaf dengan rasa tulus.

Hal ini dapat dikaitkan atau disesuaikan dengan pendapat (Wantah \& Maria, 2005) usaha pengembangan moral anak usia dini dapat dilakukan dengan strategi pembelajaran moral. Pendidikan moral dapat disamakan dengan pembelajaran nilai-nilai dan pengembangan watak yang diharapkan dapat dimanifestasikan dalam diri dan perilaku seseorang seperti kejujuran, keberanian, persahabatan, dan penghargaan.

\section{Saling Berbagi (Sedekah)}

Dialog yang menunjukkan sikap saling berbagi:

Mak Uda: "Nah anta ni (Rantang) ke rumah tok Dalang"

Upin: "Haa, buat ape?"

Ipin : "Haa, cukup keh makanan? Opah masak banyak keh?"

Mak Uda: "Cukup, bulan pause ni elok la untuk bersedekah, inikan adat kite"

Makna dialog diatas Opah meminta Upin dan Ipin untuk mengantarkan rantang berisi makanan kerumah Tok Dalang, namun Ipin meragukan cukup atau tidaknya makanan yang tersisa di rumah, kemudian Opah member tahu bahwa melaksanakan ibadah lain (sedekah) dibulan puasa itu sangat baik. Sikap saling berbagi dan member merupakan salah satu dari nilainilai kebaikan untuk dilaksanakan didalam hidup ini. Muslim yang percaya pada Tuhannya tidak memiliki keraguan sedikitpun bahwa apapun yang ia belanjakan hanya karena Allah tidak akan mengurangi kekayaannya, karena sedekah akan menambah kekayaan da tidak akan menguranginya.

Hal ini berhubungan dengan pernyataan PUSKUR (Pusat Kurikulum) 2002 dalam Setiawati (2006) Secara umum pendidikan pada anak usia dini bertujuan untuk membantu mengembangkan seluruh potensi dan kemampuan fisik, intelektual, emosional, agama dan moral secara optimal pada anak dalam lingkungan pendidikan yang kondusif, demokratis, dan kompetitif. Sementara itu nilai-nilai kepatuhan terdapat dalam penjabaran Indikator perilaku agama dan moral sejak usia 1 hingga 6 tahun, yaitu NAM.5: Melaksanakanibadah agama, dan dapat dikembangkan seperti sholat, puasa, zakat, sedekah, dsb.

\section{Tolong Menolong}

Dialog yang menunjukkan sikap Tolongmenolong:

Upin: "Akak, nak kite orang tolong?"

Kak Ros: "Tak nak."

Ipin: "Naklah kak"

Kak Ros: "Orang kate tak nak, tak nak lah..."

Mak Uda: "Alah Ros, bialah die orang tolong, duduk...duduk..!"

Makna dialog diatas menggambarkan sikap ingin menolong terhadap orang tua. Upin dan Ipin ingin membatu Opah dan Kak Ros yang sedang sibuk membuat ketupat. Meskipun belum bisa membuat ketupat akan tetapi keinginan mereka untuk membantu dan belajar sangat kuat. Sikap ini merupakan sikap yang mendidik seseorang untuk menanamkan perilaku moral yang baik.

Sikap Tolong-menolong juga terdapat dalam Indikator perkembangan agama dan moral anak usia 5-6 tahun yaitu menyayangi ciptaan Tuhan dan dapat dikembangkan pada NAM.5: Suka menolong sesama teman dan orang dewasa. 


\section{Saling Memaafkan}

Dialog yang menunjukkan sikap meminta maaf:

Upin: "Opah, nak salam. Minta maaf ye Opah, kite orang memang nakal, tapi Opah tak pernah marah, betul kan Ipin?"

Ipin: "Betul, betul, betul, kite sayang Opah, kite do'akan Opah panjang umur"

Makna dialog diatas Upin dan Ipin menunjukkan kerendahan diri dan mengakui kesalahan bahwasanya mereka memang nakal, namun mereka sadar bahwa Opah tak pernah marah. Sikap saling mema'afkan sesama manusia merupakan hal penting dalam berinteraksi, sebagaimana kita dapat meminta ma'af kepada orang lain dan sebaliknya jika kita memberi maaf orang lain yang punya kesalahan kepada kita.

Sikap saling memaafkan juga terdapat dalam indicator perkembangan agama dan moral anak usia 5-6 tahun yaitu terbiasa berperilaku sopan santun dan menghormati sesame, dalam hal ini dikembangkan pada NAM.4: Meminta maaf jika melakukan kesalahan.

\section{Terimakasih}

Dialog yang menunjukkan rasa Terimakasih:

Kak Ros: "Wah, cantiknye baju"

Upin: "Tengoklah, siape yang pakai! Kite orang yang comel"

Ipin: "Betul-betul"

Kak Ros: "Hmmmm..."

Upin: "Yela, yela, akak memang pandai jahit baju. Kite sayang akak"

Ipin: "Betul, terimakasih akak."

Makna dialog diatas adalah di pagi Raya, Upin dan Ipin sagat senang memakai baju lebaran yang dijahitkan kak Ros. Melihat kedua adik kembarnya kak Ros spontan memuji, dan tak lupa rasa terimakasih pun Upin dan Ipin ungkapkan kepada kakaknya.
Ungkapan dan rasa terimakasih juga terdapat dalam indicator perkembangan agama dan moral anak usia 5-6 tahun yaitu terbiasa berperilaku sopan santun dan menghormati sesama, dalam hal ini dapat dikembangkan pada NAM.3: Berterimakasih jika memperoleh sesuatu

\section{KESIMPULAN}

Film kartun Upin dan Ipin merupakan film yang banyak mengandung nilai moral dan agama yang seusia dengan budaya dan agama Islam. Film kartun sangat digemari oleh anak usia dini sehingga mereka dapat berlama lama menontonnya. Kandungan nilai moral dan agama anak

\section{UCAPAN TERIMA KASIH}

Kami sampaikan terima kasih kepada semua pihak yang telah membantu dalam menyelesaikan artikel jurnal ini, mudahmudahan mendapatkan balasan dari Alloh SWT. Amin

\section{DAFTAR PUSTAKA}

Ananda, R. (2017). Implementasi Nilainilai Moral dan Agama pada Anak Usia Dini. Jurnal Obsesi: Jurnal Pendidikan Anak Usia Dini, 1(1), 1931.

https://doi.org/10.31004/obsesi.v1i1.2 8

Daryanto. (2010). Media Pembelajaran (Peranannya sangat penting dalam mencapai tujuan Pendidikan). Yogyakarta: Gava Media.

Depdiknas. 2006. Undang-Undang Guru dan Dosen serta Standar Nasional Pendidikan Tahun 20

Hamid, S. I., \& Istianti, T. (2017). Rekontruksi Nilai Moral

Kewarganegaraan Berdasar Analisis Semantik Terhadap Ungkapan Kulturanl Masyarakat Sunda. Cakrawala Dini: Jurnal Pendidikan 
517 | Analisis Nilai-Nilai Agama dan Moral Anak Usia Dini dalam Tayangan Film Kartun

Anak Usia Dini, 8(1), 0-21.

Otib, S. (2005). Metode pengembangan moral dan nilai-nilai Agama. Jakarta: Universitas terbuka.

Rohmah, U. (2018). Pengembangan Karakter Pada Anak Usia Dini ( AUD ). Al-Athfal Jurnal Pendidikan Anak, 4(1), 85-102.

Sadiman, A. S., \& Dkk. (1990). Media Pendidikan. Jakarta: CV. Rajawali.

Sawyer. (2009). Internal Auditing. Buku Satu. Edisi Lama. Jakarta: Salemba Empat.

Soeparno. (1998). Ilmu dan Teknologi. Yogyakarta: Gadjah Mada University Press.

Solehudin, dkk. (2008). Pembaharuan Pendidikan di TK. Jakarta: Univrsitas Terbuka.

Sudjana dan Rivai. (2010). Media Pengajaran. Bandung: Sinar Baru Algesindo.
Sugiyono. (2011). Metode Penelitian Pendidikan Pendekatan Kuantitatif Kualitatif dan R\&D. Bandung: Alfabeta.

Sukenti, D. (2011). Media Pembelajaran (Strategi dan Aplikasi Program Media Pembelajaran di Perguruan Tinggi). STIKIP Aisyiah Riau.

Sukardi.(2003). Metodologi Penelitian Pendidikan Kompetensi dan Praktiknya. Jakarta: Bumi Aksara.

Tarigan. (2008) . Menyimak Sebagai Suatu Keterampilan Berbahasa. Bandung: Angkasa.

Tim Pena Cendikia. (2013). Panduan Mendongeng. Surakarta: Gazzamedia.

Wantah, W., \& Maria, J. (2005). Pengembangan Disiplin dan Pembentukan Moral pada Anak Usia Dini. Jakarta: Direktorat Pembinaan Pendidikan Tenaga Kependidikan an Ketenagaan Perguruan Tinggi. 